RESEARCH ASSISTANT (with a B.Sc. in microbiology or similar qualification) FOR THE HOSPITAL INFECTION UNIT IN THE DEPARTMENT OF BACTERIOLOGY
-Clerk to the Governors, St. Bartholomew's Hospital, London, E.C.1,

quoting Project No. 102/2, reference No. ASC/465. RESFARCH ASSISTANT (with a degree in chemistry and some experience in
a field of polymer research) IN POLYMER CHEMISTR - The Registrar, Ref.

118Y/X, Bradford Institute of Technology, Bradford, 7 . RESEARCH BIOCHEMIST (under 35 , biochemist or biologist with a Ph.D.) for biochemical and immunochemical research on lipocarbohydrates-The Personnel Director, Evansto

RESEARCH SCIENTISTS (graduates or equivalent in chemistry, physics or wood science) for investigations into (a) glueing of timber and composite materials; and (b) wood finishes: paints, varnishes, stains, water repellents, etc.-The Secretary, Timber Research and Development Association, St. John's Road, Tylers Green, High Wycombe, Bucks.

SOIENTIFIC OFFICER/SENIOR SCIENTIFIC OFFICER (honours graduate in bacteriology or microbiology) IN THE BACTERIOLOGY DEPARTMENT, for work concerned with the role of micro-organisms in the nutrition of the ruminant-The Secretary, National Institute for Research in Dairying (University of Reading), Shinfleld, Reading, Berkshire, quoting Ref, 65/3. SENIOR or CHIEF TECHNICIAN (with a good knowledge of workshop practice and some experience of vacuum techniques and electronics) to work with a research group on atomic beam research projects, concerned with gas scattering, optical and electron excitation and radio-frequency resonance-The Laboratory Superintendent, Physics Laboratory, University of Sussex, Falmer, Brighton, Sussex.

TECHNICIAN or JUNIOR TECHNICIAN for research work in the Pathology Department-The Secretary, St. Mary's Hospital Medical School, Paddington, London, W.2.

VIROLOGIST (or a Biologist with some virological experience) to work on a joint research enterprise between the National Institute for Medical Research and the Department of Biochemistry, Imperial College. The work will involve study of antiviral substances in animals and in tissue culture-The
Director, National Institute for Medical Research, Mill Hill, London, N.W.7.

\section{REPORTS and other PUBLICATIONS}

\section{Great Britain and Ireland}

Joint Mathematical Council of the United Kingdom. Report on In-Service Hon. Secretary, Joint Mathematical Council of the United Kingdom, c/o
King's College, 1965.) International Nickel, Ltd. Ni-Resist Irons for Fluid Handling in the Chemical Industry. Pp. 8. (London: International Nickel, Ltd., 1965.) [127 Agricultural Research Council. Slatted Floor Systems for Pigs: a Review
f Research Literature to 31 st December 1964. By P. H. Easton and C. N Hesearch Literature to 31st December 1964. By P. H. Easton and C. N.
Harvey. Pp. 24. (London: Agricultural Research Council, 1965. Obtainable Harvey. Pp. 24. (London: Agricultural Research Council, 1965. Obtainable
from H.M. Stationery Office.) 28. 6 d. net. British Empire Cancer Campaign for Research. Forty-Second Annual Report covering the year 1964. Part 1: The Chairman's Statement and the Accounts of the Central Organisation. Pp. xxxvi. Part 2: The Scientific Report of the Research Undertaken by the Central Organisation and Its Organisations Overseas. Pp. xxxvii + 705. (London: British Empire Cancer Campaign for Research, 1965 .)

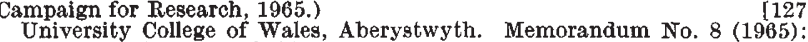
Synopsis of Discussions held on March 1st, 1965, on the subject of Climatic Change, with special reference to Wales and Its Agriculture. Edited by 1965 .

The British Steel Castings Research Association. 12th Annual Report 1965. Pp. ii + 43. (Sheffield: The British Steel Castings Research Association, Colleges offering Courses Ieading to the Certificates of The City and Guilds of London Institute in Concrete Practice, Conerete Technology (Supervisory Level); Formwork and Shuttering for Concrete Construction; Structural Detailing, 1965-66. Pp. 12. (London: Cement and Concrete Association, 1965.) (A.R.L.), Ltd. Technical Notes (June 1965): Ciba Resins in Ireland.
Ciba Pp. 8. (Duxford: Ciba (A.R.L.), Ltd., 1965.)
British Museum (Natural History). Instructions for Collectors, No. 3: British Museum (Natural History). Instructions for Collectors, No. 3: Fishes. Pp. 17. 1s. 6d. Fossil Amphibians and Reptiles. By W. E. Swinton.
Fourth edition. $\mathrm{Pp}$. ix $+133+17$ plates. 5s. Bulletin of the British Museum Fourth edition. Pp. ix $+133+17$ plates. 5s. Bulletin of the British Museum
(Natural History). Geology. Vol. 10, No. 6: The Generic Position of Osmun(Natural History). Geology Vol. 10, No. 6: The Generic Position of Osmun-
dites dowkeri Carruthers. By Marjorie E. J. Chandler. Pp. 139-161+12 plates. 42s. Vol. 11, No. 1: The Head of Dipterus valenciennesi, Sedgwick and Murchison. By Errol Ivor White. Pp. $1-45+3$ plates. 258. (London: British Museum (Natural History), 1965.) [127 University of Oxford. Changes in Regulations made by Boards of Faculties.
Pp. 34. (Supplement No. 8 to the University Gazette, June 1965.) (Oxford: Pp. 34. (Supplement No. 8 to the University Gazette, June 1965.) (Oxford:
The University, 1965.) 28 . 6d. Government of Northern Ireland: Ministry of Agriculture. Leaflet No. 61 : The Care and Management of Breeding Bulls. Pp. 8. Leaflet No. 67: The Cultivation of Vegetables. Pp. 19. Leaflet No. 73: Potatoes. Pp. 16. Agriculture. Pp. 6. (Belfast: Ministry of Agriculture, 1965.) Careers
[127 Bulletins of Marine Ecology, Vol. 6, Part 4: Continuous Plankton Records - Contribution Towards a Plankton Atlas of the North Atlantic and the Pp. 104-1. Part 9: Seasonal Cycles of Phytoplankton. By G. A. Robinson. Association, 1965.)
[127 The British Institute of Radiology. Annual Report of Council for Session 1964-5. Pp. 7. (London: The British Institute of Radiology, 1965.) [127
Sheffield City Libraries. Bulletin of the Libraries of Commerce, Science and Technology, No. 1, July, 1965. Pp. 18. (Sheffield: Sheffield City Libraries, 965.)
Water Resources Board. Morphometric Analysis of River Basin Characteristics. By Gérard Boulton. Pp. 10. (T.N.2.) (Reading: Water Resources
Board, 1965.) Board, 1965.)
Gencral Register Office. The Registrar General's Quarterly Return for Gencral Register Office. The Registrar General's Quarterly Re
England and Wales-Births, Deaths and Marriages; Infectious Diseases; Weather; Population Estimates, Quarter ended 31st March 1965 (No. 465,
lst Quarter 1965). Pp. 32. (London: H.M. Stationery Office, 1965.) 2s, 6d. net. 1127 1984/5. Pp. 59. (Chislehurst, Kent: The British Scientific Instrument Research Association, 1965.)

\section{Other Countries}

Proceedings of the United States National Museum, Smithsonian Institu tion. No. 3506, Vol. 116: Review of the Genus Cerceris in America North of Mexico (Hymenoptera: Sphecidae). By Herman A. Scullen. Pp. 333-548. No. 3507, Vol. 116: North American Moths of the Genus Swammerdamia
(Lepidoptera: Yponomeutidae). By W. Donald Duckworth. Pp. 549-556. (Lepidoptera: Yponomeutidae). By W. Donald Duckworth. Pp. 549-556.
(Washington, D.C.: Government Printing Office, 1965.) (Washington, D.C.: Government Printing Office, 1965.)
Suomen Geodeettisen Laitoksen Julkaisuja-Veröffentlichungen des Finnischen Geodätischen Institutes. No. 60: General List of Astronomical
Azimuths Observed in 1920-1959 in the Primary Triangulation Net. By Azimuths Observed in $1920-1959$ in the Primary Triangulation Net. By
V. R. Olander. Pp. 46. (Helsinki: Geodeettinen Laitos, 1965.) Annals of the New York Academy of Sciences, Vol. 122, Article 2: The Annals of the New York Academy of Sciences, Vol. 122, Article 2: The
Laser. By Leon Goldman, Joseph Weber and 53 other authors. Pp. 571-834. (New York: New York Academy of Sciences, 1965.) 7 dollars. Pp. 571-834.
[147 Institutt for Atomenergi, Kjeller. Survey of Activities 1964. Pp. 27 (Kjeller: Institutt for Atomenergi, 1965.)
Annual Report for the year 1963 of The South African Institute for Medical Research. Pp. 228. (Johannesburg: The South African Institute for Medical Research, 1965.)
I147 Bertil Flodin, Albertsgatan $19 \mathrm{~B} 17,1965$.)
[147 Comité International des Poids et Mesures. Procès-Verbaux des Séances, Gauthier-Villars et Cie., 1965.)

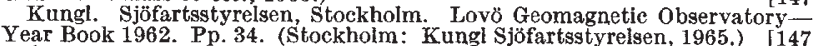
Institute of Sera and Vaccines, Praha. Collection of Summaries, Vol 4 Papers Published by the Scientific Workers of the Institute in 1964. Pp. 32 . (Praha: Institute of Sera and Vaccines, 1965.) United States Department of the Interior: Fish and Wildlife Service.
Bureau of Sport Fisheries and Wildlife. Circular 223: Survival or Surrender for Endangered Wildlife. Pp. 15. (Washington, D.C.: Government Printing Office, 1965.) 15 cents. Verebungsforschung-Société Suisse de Génétique (S.S.G.) 1964. Mit

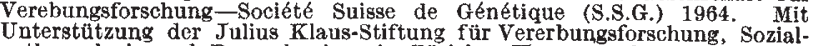
Unterstützung der Julius Klaus-Stiftung für Vererbungsforschung, Sozialanthropologie und Rassenhygiene in Zürich. Herausgegeben von Marthe Ernst-Schwarzenbach. (Separatabdruck aus Archiv der Julius KlausStiftung für Verebungsforschung, Sozialanthropologie und Rassenhygiene,
Band XXXIX, 1964, Heft 1/4.) Pp. 131. (Zürich: Art. Institut Orell Fussli, AG., 1965.)
Geological Survey of Tanzania. Bulletin No. 36: Microflora from the Ketewaka-Mchuchuma Coalfield, Tanganyika. By Dr. George F. Hart. Pp. $27+1$ plate. Shs. 55/-. Bulletin No. 37: The Geology of the Uluguru
Mountains. By D. N. Sampson and A. E. Wright. Pp. v $+69+7$ plates. Mhs. 15/-. Explanatory Notes on the Geological Map of Kilimanjaro (Covering Quarter Degree Sheets 42, 56 and 57). Pp.9. Shs. 6/-. (Dodoma: Geological
Survey of Tanzania, 1964 and 1965.)

Publications of the Dominion Astrophysical Observatory, Victoria. Vol. 12, No. 7: Line Intensities in the Spectra of Representative Stars of Spectral Types B to G. By K. O. Wright, E. K. Lee, T. V. Jacobson and Spectra of Some M-, S- and C-Type Stars. By Yoshio Fujita, Yasumasa Yamashita, Fumuo Kamijo, Takashi Tsuji and Kazuhiko Utsumi. Pp. 293-316. Vol. 12, No. 9: Spectroscopic Absolute Magnitudes of Early-Type
Stars from Hydrogen Absorption-a Revision. By R. M. Petrie. Pp. 317-338. Stars from Hydrogen Absorption-a Revision. By R. M. Petrie. Pp. 317-338.
(Victoria, B.C.: Dominion Astrophysical Observatory, 1965.)
[147 Académie Royale de Belgique. Annuaire pour 1965 (Nr. 131). Pp. 563.
(Bruxelles: Académie Royale de Belgique, 1965.) (Bruxelles: Académie Royale de Belgique, 1965.)
United States Department of the Interior: Geological Survey. Bulletin 1193: Bibliography of Reports Resulting from U.S. Geological Survey Participation in the United States Technical Assistance Program, 1940-65.
By Jo Ann Heath. Pp. vi + 51. 25 cents. Bulletin 1201-D: Chemical Comparison of Glassy and Crystalline Volcanic Rocks. By P. W. Lipman. Southern Part of the Mule Mountains, Arizona. By Philip T. Hayes and Edwin R. Landis. Pp iii $+43+$ plate 1. 45 cents. Water-Supply Paper 1791: Hydrologic Conditions Near Glendo, Platte County, Wyoming. By
George E. Welder and Edwin P. Weeks. Pp. v $82+$ plates 1-3. WaterSupply Paper 1793: Ground Water in the East Portland Area, Oregon. By ton, H.C.: Government Printing Office, 1965.)
tong 1 and 2. (Washington, D.C.: Government Printing Office, 1965.) Geological Survey. WaterSupply Paper 1809-A: Ground Water Resources of the Jenkins-Whitesburg Area, Kentucky. By D. S. Mull. Pp. iv $+36+$ plates 1 and 2 . Geophysical Virginia S. Neuschel, and others. Pp. iii $+433-521$. 35 cents. Professional Paper 484: Geomorphology of the Shenandoah Valley, Virginia and West Virginia, and Origin of Residual Ore Deposits. By John T. Hack. Pp. iv $+84+$ plates 1-3. Professional Paper 447: The Comanche Series and Associated Rocks in the Subsurface in Central and South Florida. By Paul L. Applin and Eisther R. Applin, Pp. v+84+ plates 1-11. (Washington, D.C.: Institut Royal Météorologique de Belgique. Publications, Série B, No. 45 . Le Temps en 1964. Par Dr. R. Sneyers. Pp. 54. (Uccle-Bruxelles: Institut Royal Météorologique de Belgique, 1965.)
Smithsonian Institution-United States National Museum. Iulletin 243. Smithsonian Institution-United States National Museum. Bulletin 243:
Lacebugs of the World: a Catalog (Hemiptera: Tingidae). By Carl J. Drake Lacebugs of the World: a Catalog (Hemiptera: Tingidae). By Carl J. Drake Smithsonian Institution, 1965.)

\section{Editorial and Publishing Offices of "NATURE" \\ MACMILLAN (JOURNALS) LIMITED \\ 4 LITTLE ESSEX STREET, LONDON, W.C. 2}

Telephone Number: Temple Bar 6633. Telegrams: Phusis London W.C.2

Annual subscription: Inland $£ \mid 4$, Overseas $€ \mid 3$ I5s., payable in advance, postage paid to any part of the world.

Advertisements only should be addressed to

T. G. Scott \& Son, Led., I Clement's Inn, London, W.C.2. Telephone Number: Holborn $\mathbf{4 7 4 3}$

Registered as a newspaper at the General Post Office Copyright (C) Macmillan (Journals) Limited, August 21, 1965 